\title{
FATE OF NICKEL ION IN (II-III) HYDROXYSULPHATE GREEN RUST SYNTHESIZED BY PRECIPITATION AND COPRECIPITATION ${ }^{(1)}$
}

\author{
Lucia Helena Garófalo Chaves ${ }^{(2)}$, Joan Elizabeth Curry ${ }^{(3)}$, David \\ Andrew Stone ${ }^{(4)} \&$ Jon Chorover ${ }^{(5)}$
}

\begin{abstract}
SUMMARY
In order to investigate the efficiency of sulfate green rust (GR2) to remove $\mathrm{Ni}$ from solution, GR2 samples were synthesized under controlled laboratory conditions. Some GR2 samples were synthesized from Fe(II) and Fe(III) sulfate salts by precipitation. Other samples were prepared by coprecipitation, of $\mathrm{Ni}$ (II), $\mathrm{Fe}(\mathrm{II})$ and $\mathrm{Fe}$ (III) sulfate salts, i.e., in the presence of $\mathrm{Ni}$. In another sample, $\mathrm{Ni}$ (II) sulfate salt was added to pre-formed GR2. After an initial X-ray diffraction (XRD) characterization all samples were exposed to ambient air in order to understand the role of $\mathrm{Ni}$ in the transformation of the GR2 samples. XRD was repeated after 45 days. The results showed that Nious GR2 prepared by coprecipitation is isomorphous to Ni-free GR2, i.e. $\mathrm{Ni}$ is incorporated into the crystalline structure. $\mathrm{Fe}$ (II) was not replaced by $\mathrm{Ni}$ (II) in the crystalline structure of GR2 formed prior to exposure to solution-phase $\mathrm{Ni}$. This suggests $\mathrm{Ni}$ was adsorbed to the GR2 surface. Sulfate green rust is more efficient in removing $\mathrm{Ni}$ from the environment by coprecipitation.
\end{abstract}

Index terms: nickel incorporation, nickel adsorption, X-ray diffraction, isomorphous substitution.

\footnotetext{
(1) Part of the research developed at the University of Arizona, supported by CAPES, during the postdoctoral training period of the first author. Recebido para publicação em janeiro de 2006 e aprovado em março de 2007.

${ }^{(2)}$ Full Professor at the Universidade Federal de Campina Grande, Department of Agricultural Engineering. Caixa Postal 10087, CEP 58109-970 Campina Grande (PB), Brazil. E-mail: lhgarofalo@hotmail.com

(3) Associate Professor at the University of Arizona, Department of Soil, Water and Environmental Science. Tucson, Az, 85721, USA. E-mail: curry@ag.arizona.edu

(4) Graduate Student at the University of Arizona, Department of Soil, Water and Environmental Science. Tucson, Az, 85721, USA. E-mail: dstone@u.arizona.edu

(5) Professor at the University of Arizona, Department of Soil, Water and Environmental Science. Tucson, Az, 85721,USA. Email: chorover@cals.arizona.edu
} 


\title{
RESUMO: ADSORÇÃO DE ÍON NÍQUEL EM (II-III) GREEN RUST HIDROXISULFATO SINTETIZADO POR PRECIPITAÇ̃̃O E CO- PRECIPITAÇÃO
}

\begin{abstract}
Com objetivo de investigar a eficiência do "sulfate green rust" (GR2) na remoção de Ni da solução, amostras de GR2 foram sintetizadas em laboratório sob condições controladas. Algumas amostras de GR2 foram sintetizadas pela precipitação de sais de $\mathrm{Fe}(I I)$ e de $\mathrm{Fe}(I I I)$; outras amostras, pela co-precipitação de sais de Ni(II), Fe(II) e de Fe(III); e em outras amostras, o sulfato de Ni(II) foi adicionado às amostras GR2 pré-formadas. Após caracterização inicial, por difração de raios $X$, todas as amostras ficaram expostas ao ar atmosférico durante 45 dias, a fim de se avaliar o papel do Ni na transformação delas. Após esse período, a difração de raios $X$ das amostras foi repetida. Os resultados mostraram que Ni-GR2 preparado por co-precipitação é isomórfico do GR2, estando o íon Ni na estrutura cristalina deste. $\mathrm{Fe}(I I)$ não foi substituído por Ni(II) na estrutura cristalina de GR2 formado a priori. Talvez o íon Ni tenha sido adsorvido na superfície do GR2. O sulfato "green rust" é eficiente para remover Ni do ambiente somente por co-precipitação.
\end{abstract}

Termos de indexação: incorporação de níquel, adsorção de níquel, difração de raios $X$, substituição isomórfica.

\section{INTRODUCTION}

Green rust is a Fe(II)-Fe(III) hydroxide that consists of positively charged brucite-like layers alternating with anions and water molecules. The general composition $\left[\mathrm{Fe}^{\mathrm{II}}{ }_{(6-\mathrm{x})} \mathrm{Fe}^{\mathrm{III}}(\mathrm{OH})_{12}\right]^{\mathrm{x}+}\left[(\mathrm{A})_{\mathrm{x} / \mathrm{n}} \cdot \mathrm{yH}_{2} \mathrm{O}\right]^{\mathrm{x}-}$ where $\mathrm{x}=0.9-4.2, \mathrm{~A}$ is an $\mathrm{n}$-valent anion, e.g., $\mathrm{CO}_{3}{ }^{2-}, \mathrm{Cl}^{-}$or $\mathrm{SO}_{4}{ }^{2-}$ and y denotes the varying amounts of interlayer water (O'Loughlin et al., 2003). The green rust with a hexagonal cell, containing sulfate anions in the interlayer spaces, is called green rust two (GR2) and has been studied in detail. It is known that the $\mathrm{Fe}$ (III) ions in the brucite-like sheet and the $\mathrm{SO}_{4}{ }^{-2}$ anions in the interlayer spaces in GR2 exhibit long range order (Génin, 2004).

Green rusts are found as natural corrosion products of $\mathrm{Fe}$ metal (Refait et al., 2003) and as minerals in hydromorphic soils (Génin et al., 2001). They can be synthesized in the laboratory by partial $\mathrm{Fe}$ oxidation (II) or by reactions of $\mathrm{Fe}$ (II) and $\mathrm{Fe}$ salts (III) in aqueous solutions (Géhin et al., 2002). Green rusts, unlike most Fe oxides, have a large internal surface area giving rise to great specific surface areas and consequently great reactivity. They represent reactive ion exchangers and sorbents (Hansen et al., 2001). The amphoteric surface hydroxyl groups can sorb heavy metals (cations) as well as inorganic anions, e.g. silicate, arsenate and selenate. In addition, cations such as $\mathrm{Cu}(\mathrm{II}), \mathrm{Ni}(\mathrm{II})$, $\mathrm{Zn}(\mathrm{II}), \mathrm{Cd}(\mathrm{II}), \mathrm{Co}(\mathrm{II})$ and $\mathrm{Mg}(\mathrm{II})$, may isomorphically substitute for $\mathrm{Fe}$ (II) during green rust formation (coprecipitation). Refait et al. (1990, 1994, 2005) have obtained Nious-ferric green rusts as the end products of substitution of $\mathrm{Fe}$ (II) ions by $\mathrm{Ni}$ (II) ions in green rust. This has implications for the fate of transition metals in the environment.
Green rusts are unstable in oxidizing conditions and their rapid reaction with atmospheric oxygen results in the formation of ferrihydrite $\left(\mathrm{Fe}_{5} \mathrm{HO}_{8} \cdot 4 \mathrm{H}_{2} \mathrm{O}\right)$, goethite $(\alpha-\mathrm{FeOOH})$, akaganeite $(\beta-\mathrm{FeOOH})$, lepidocrocite $(\gamma-\mathrm{FeOOH})$, hematite $\left(\alpha-\mathrm{Fe}_{2} \mathrm{O}_{3}\right)$ maghemite $\left(\gamma-\mathrm{Fe}_{2} \mathrm{O}_{3}\right)$ or magnetite $\left(\mathrm{Fe}_{3} \mathrm{O}_{4}\right)$, depending on $\mathrm{pH}$, solution composition, oxidant, oxidation rate, and the dehydration degree and rate (Lin et al., 1996; Loyaux-Lawniczak et al., 2000).

Working with $\mathrm{Ni}(\mathrm{II})$-Fe(II)-Fe(III) pyroaurite-like hydroxychlorides obtained by aerial oxidation of mixed $\mathrm{Ni}$ (II)-Fe(II)-hydroxides with various $\mathrm{P}=\mathrm{Fe} / \mathrm{Ni}$ ratios, Refait \& Genin (1997) observed that these hydroxychlorides oxidize quickly and the final product depends on $\mathrm{P}$. In the absence of $\mathrm{Ni}$, green rust oxidized to lepidocrocite. For $\mathrm{P}>5 / 3$ the X-Ray diffraction (XRD) analyses revealed lepidocrocite and some $\mathrm{Ni}$ (II)-Fe(II) hydroxychloride while for $\mathrm{P}$ between $1 / 3$ and 5/3, only hydroxychloride appeared on the XRD diagram.

The incorporation of cationic inorganic contaminants into the green rust structure may be an effective means of sequestering contaminants in the subsurface. However, the potential of green rusts to adsorb or incorporate contaminants into the crystal structure and the tendency to release them again to solution depends on the conditions during initial GR2 formation by precipitation or coprecipitation, the transformation processes to more stable phases, as well as the susceptibility to dissolve and therefore release incorporated trace components.

In view of the potential importance of GR2 in environmental pollution control, this study investigated the fate of $\mathrm{Ni}$ ions in GR2 formed by precipitation in the absence and in GR2 formed by coprecipitation in the presence of $\mathrm{Ni}$. 


\section{MATERIAL AND METHODS}

Since GR2 is very sensitive to air oxidation, the GR2 samples were synthesized in an anoxic chamber (glovebox). The preparation method of some samples was similar to that described by Géhin et al. (2002), i.e., the first GR2 samples were synthesized by precipitating a mixture of $\mathrm{Fe}$ (II) and $\mathrm{Fe}$ (III) sulfate salts with Na hydroxide. Ferrous sulfate heptahydrate $\mathrm{FeSO}_{4} \cdot 7 \mathrm{H}_{2} \mathrm{O}$ and ferric sulfate pentahydrate $\mathrm{Fe}_{2}\left(\mathrm{SO}_{4}\right)_{3} \cdot 10 \mathrm{H}_{2} \mathrm{O}$ were then rapidly dissolved in $100 \mathrm{~mL}$ of $\mathrm{N}_{2}$-purged deionized water. A ratio of $[\mathrm{Fe}(\mathrm{II})] /[\mathrm{Fe}(\mathrm{III})]=3$ was used with $\{[\mathrm{Fe}(\mathrm{II})]+[\mathrm{Fe}(\mathrm{IIII})]\}$ $=0.2 \mathrm{~mol} \mathrm{~L}^{-1}$. The initial Fe(III) concentration in all samples was $0.05 \mathrm{~mol} \mathrm{~L}^{-1}$. The ratio $\mathrm{P}=[\mathrm{Fe}(\mathrm{II}) / \mathrm{Ni}(\mathrm{II})]$ was $100 \% \mathrm{Fe}(\mathrm{II})$ and $0 \% \mathrm{Ni}(\mathrm{II})$. Magnetic stirring ensured a fast and complete dissolution. Then, $100 \mathrm{~mL}$ of $0.6 \mathrm{~mol} \mathrm{~L}^{-1} \mathrm{NaOH}$, corresponding to a final $\left[\mathrm{OH}^{-}\right] /\{[\mathrm{Fe}(\mathrm{II})]+[\mathrm{Fe}(\mathrm{III})]\}$ ratio of $3 / 2$, was added to the solution under continuous stirring. After one hour, the stirring was stopped, the $\mathrm{pH}$ determined between 6.4 and 6.8 and the samples were aged in the flask for $24 \mathrm{~h}$ (sample 1).

A second sample set (sample 2) was synthesized by coprecipitating a mixture of $\mathrm{Fe}$ (II), $\mathrm{Ni}$ (II) and $\mathrm{Fe}$ (III) sulfate salts with $\mathrm{Na}$ hydroxide. Ferrous sulfate heptahydrate $\mathrm{FeSO}_{4} .7 \mathrm{H}_{2} \mathrm{O}$, Ni sulfate hexahydrate $\mathrm{NiSO}_{4} \cdot 6 \mathrm{H}_{2} \mathrm{O}$ and ferric sulfate pentahydrate $\mathrm{Fe}_{2}\left(\mathrm{SO}_{4}\right)_{3} \cdot 10 \mathrm{H}_{2} \mathrm{O}$ were dissolved in $100 \mathrm{~mL}$ of $\mathrm{N}_{2}$ purged deionized water. A ratio of $[\mathrm{Fe}(\mathrm{II})+\mathrm{Ni}(\mathrm{II})] /$ $[\mathrm{Fe}(\mathrm{III})]=3$ was used with $\{[\mathrm{Fe}(\mathrm{II})]+[\mathrm{Ni}(\mathrm{II})]+$ $[\mathrm{Fe}(\mathrm{III})]\}=0.2 \mathrm{~mol} \mathrm{~L}^{-1}$. The ratio $\mathrm{P}=[\mathrm{Fe}(\mathrm{II}) / \mathrm{Ni}(\mathrm{II})]$ was $60 \% \mathrm{Fe}(\mathrm{II})$ and $40 \% \mathrm{Ni}(\mathrm{II})$. The solution was magnetically stirred to ensure fast and complete dissolution. Then, $100 \mathrm{~mL}$ of $0.6 \mathrm{~mol} \mathrm{~L}^{-1} \mathrm{NaOH}$, corresponding to a final ratio of $\left[\mathrm{OH}^{-}\right] /\{[\mathrm{Fe}(\mathrm{II})+$ $\mathrm{Ni}(\mathrm{II})]+[\mathrm{Fe}(\mathrm{III})]\}=3 / 2$, was added to the solution under continued stirring as described above. After one hour stirring, the $\mathrm{pH}$ was measured and the samples aged in flasks for $24 \mathrm{~h}$.

The third sample set (sample 3) was initially prepared like sample $1(\mathrm{P}=100 \% \mathrm{Fe}$ (II) and $0 \%$ $\mathrm{Ni}(\mathrm{II})$ ), but after the magnetic stirring the samples were aged for one week. Then the same amount of $\mathrm{Ni}(\mathrm{II})$ used in sample 2 was added to each flask. The GR2-Ni mixtures were magnetically stirred for one hour and aged for another $24 \mathrm{~h}$. In this case the GR2 samples had been pre-formed prior to contact with Ni.

The samples were centrifuged and the supernatants decanted and stored for further analysis. The precipitates were subsequently washed two times with $\mathrm{N}_{2}$-purged deionized water. The solutions decanted from the washing process were also collected and stored for further analysis. A small amount of nitric acid was added to the decanted supernatant solutions to avoid the precipitation of $\mathrm{Fe}$ (III) oxyhydroxides. The supernatants were analyzed for
Fe(II) with ferrozine according to the method of Stookey (1970) using an UV-Vis recording spectrophotometer (UV-250 IPC). The Ni(II) concentration was determined by an atomic absorption spectrophotometer. The molar amounts of $\mathrm{Fe}$ (II) and $\mathrm{Ni}$ (II) in the GR2 samples were calculated as the difference between the amount used initially to synthesize GR2 and the remaining amount found in the supernatant. The GR2 precipitates were dried within the glovebox and ground to powder. The dried samples were characterized by X-ray diffraction (XRD). The XRD analysis was performed on a Philips X'Pert Pro MPD diffractometer using $\mathrm{CuK} \alpha(1.5418 \AA$ A radiation and an X'Celerator RJMS array detector. The samples were placed in air-tight glass vials prior to removal from the glove box. Each sample was quickly transferred to an XRD sample holder (air exposure $\leq$ five minutes) and XRD-analyzed. The crystallographic parameters, i.e. interplanar distances (c) and dimension of the unit cell along the a-axis (a) of the samples were calculated with the XRD data by the Scherrer formula, i.e., $D_{c}=0.9 \lambda[\varepsilon \cos \theta]^{-1}$ where $\varepsilon$ is the full width at half maximum of a diffraction line at a Bragg angle of $\theta$ (Refait \& Genin, 1997).

After this initial XRD characterization all samples were exposed to ambient atmosphere to understand the role of $\mathrm{Ni}$ in the transformation of the GR2 samples. XRD was repeated after 45 days.

\section{RESULTS AND DISCUSSION}

All main lines found in the XRD patterns (Figure 1) are similar and typical of GR2 suggesting that the crystallographic structure of the samples is similar. The XRD plot for GR2 with no Ni is shown for reference (Figure 1a). The peak positions match those reported for GR2. Even when Ni was coprecipitated with Fe(II) and $\mathrm{Fe}(\mathrm{III})$, the characteristic green rust peaks persisted (Figure 1b) suggesting that $\mathrm{Ni}$ is incorporated in the sulfate layer of GR2 (Refait et al., 1990). Part of the Fe(II) was probably substituted by $\mathrm{Ni}$ (II) in the crystallographic structure, resulting in $\mathrm{Ni}(\mathrm{II})-\mathrm{GR} 2$, which is isomorphous to GR2 (Refait et al., 1994). The peak positions for the sample prepared by GR2 precipitation followed by $\mathrm{Ni}$ exposure one week later (Figure 1c) were also similar to the peak positions for the sample prepared with no $\mathrm{Ni}$ (Figure 1a), suggesting that later exposure to Ni did not influence the GR2 structure.

The angular position of the diffraction peaks leads to a series of $c$ spacings close to those described by Bernal et al. (1959) which characterize the GR2 structure that is known to be a hexagonal lattice. Table 1 shows the interplanar distances $(c)$ and the dimensions of the unit cell along the a-axis (a) for all samples produced here as calculated from the XRD patterns. 


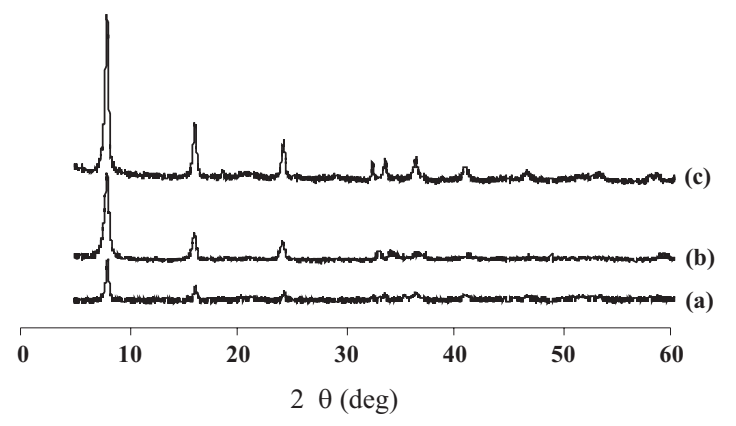

Figure 1. X-ray diffraction patterns for GR2 samples 1, 2 and 3 (a), (b) and (c): sample without nickel; sample prepared by coprecipitation of $\mathrm{Ni}(\mathrm{II})$, $\mathrm{Fe}$ (II) and Fe(III); sample with nickel added one week after GR2 precipitation, respectively.

Even though the XRD patterns for the three samples look similar it is possible to understand the influence of $\mathrm{Ni}$ on the samples by comparing the lattice parameters for samples prepared with and without the element. Crystallographic parameters (a and $c$ ) for sample 1 are similar to those found by Bernal et al. (1959) to characterize the structure of GR2 $(a=$ $0.32 \mathrm{~nm}$ and $c=1.09 \mathrm{~nm}$ ), confirming that this sample is pure GR2. For all three samples the cvalues were close to the value $1.097 \mathrm{~nm}$ found for pure GR2 and there was no apparent correlation with the presence of $\mathrm{Ni}$ in the crystallographic structure. This indicates that, in this case, either the accuracy was insufficient to distinguish a trend or the c-value is not sensitive to $\mathrm{Fe}(\mathrm{II})$ substitution by $\mathrm{Ni}(\mathrm{II})$.
Contrastingly, the a-value for sample 2 was lower than for samples 1 and 3 . This is consistent with the fact that $\mathrm{Fe}(\mathrm{II})$ is larger than $\mathrm{Ni}(\mathrm{II})$. The a-value for the pure $\mathrm{Ni}$ brucite sheet, $\mathrm{Ni}(\mathrm{OH})_{2}$, is $0.3126 \mathrm{~nm}$ (Graves $\&$ Thomas, 1986) whereas the a-value for the pure ferrous brucite sheet, $\mathrm{Fe}(\mathrm{OH})_{2}$, is larger by $0.3262 \mathrm{~nm}$ (Bernal et al., 1959). The substitution of Fe(II) by $\mathrm{Ni}$ (II) in any brucite-like compound should therefore result in a decrease in the lateral dimension of the unit cell. This suggests that there is isomorphic substitution of Fe(II) by Ni(II) in the GR2 structure. The a-values of samples 1 and 3 are similar to each other. This supports the idea that these samples have the same crystalline structure and that the Ni associated with sample 3 added one week after Fe(II) and Fe(III) precipitation is probably adsorbed at the GR2 surface.

The similar molar amounts of Fe(II) in samples 1 and 3 (Table 2) also support the idea that Fe(II) in sample 3 was not substituted by $\mathrm{Ni}$ (II), in contrast to sample 2 where the molar amount of $\mathrm{Fe}(\mathrm{II})$ is much lower.

Green rust 2 is unstable and oxidizes quickly when exposed to the atmosphere. In order to determine the extent to which the GR2 structure is retained in oxidizing conditions, the samples were exposed to ambient atmosphere for 45 days and then reexamined by XRD (Figure 2). In a comparison of the patterns in figure 2 and 1 , the characteristic GR2 peaks in samples 1 and 3 (Figure $2 \mathrm{a}$ and 2c, respectively) had practically disappeared indicating that the original compounds were transformed and the original GR2 structure was lost.

Table 1. Interplanar distances (c) and dimensions of the unit cell along the a-axis (a) for GR2 samples 1,2 and 3: without nickel; prepared by coprecipitation of $\mathrm{Ni}$ (II), Fe(II) and Fe(III); with nickel added one week after GR2 precipitation, respectively
Crystallographic parameter
Sample 1
Sample 2
Sample 3

\begin{tabular}{|c|c|c|c|}
\hline \multirow[b]{2}{*}{$c$} & \multicolumn{3}{|c|}{$-\mathrm{nm}$} \\
\hline & 1.0974 & 1.0963 & 1.0987 \\
\hline$a$ & 0.3173 & 0.3134 & 0.3178 \\
\hline
\end{tabular}

Table 2. Molar amounts of Fe(II) and Ni(II) in GR2 samples

\begin{tabular}{ccc}
\hline GR2 samples & Fe (II) & Ni (II) \\
\hline & & \\
Sample 1 & 1.95 & 0 \\
Sample 2 & 1.01 & 0.87 \\
Sample 3 & 1.99 & 0.13 \\
\hline
\end{tabular}


In contrast, for sample 2 (Figure $2 \mathrm{~b}$ ) the three main peaks typifying green rust were still present even after exposure to oxidizing conditions. The additional peaks indicate that other minerals are present in the sample, aside from GR2.

Considering that the XRD analysis provides no information on the location of the $\mathrm{Ni}$ ion in the compound structure and knowing that $\mathrm{Ni}$ is able to decrease the oxidation process of Ni-GR2, as observed by Refait et al. (1990), one can infer that in sample 2 (Figure 2b) the Ni ions are part of the GR2 structure and that in sample 3 (Figure 2c) any Ni associated with GR2 was adsorbed at the surface, since it did not prevent sample oxidation.

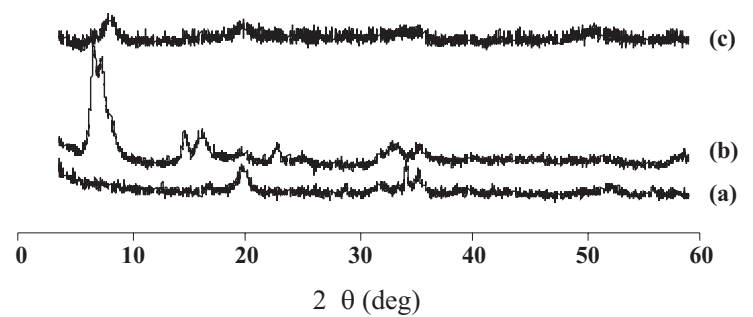

Figure 2. X-ray diffraction patterns of the GR2 samples 1, 2 and 3 (a), (b) and (c) after air exposure: sample without nickel; sample prepared by coprecipitation of $\mathrm{Ni}(\mathrm{II}), \mathrm{Fe}$ (II) and Fe(III); sample with nickel added one week after GR2 precipitation, respectively.

\section{CONCLUSION}

The results of this study support the hypothesis that Ni ions added to GR2 synthesized by Ni-free precipitation are adsorbed on the GR2 surface and that $\mathrm{Fe}(\mathrm{II})$ is not replaced by $\mathrm{Ni}(\mathrm{II})$ in the GR2 crystalline structure. Contrastingly, GR2 formed by coprecipitation of $\mathrm{Ni}$ and $\mathrm{Fe}$ ion is isomorphous to GR2. $\mathrm{Ni}(\mathrm{II})$ is present in the GR2 crystalline structure. Coprecipitation results in removal of $\mathrm{Ni}$ from solution and may be more efficient in removing the element from the environment than adsorption.

\section{ACKNOWLEDGEMENTS}

The authors are indebted to the University of Arizona, departments Agricultural and Biosystems Engineering and Soil, Water and Environmental Science for support. We wish to thank Mary Kay Amistadi for assistance with the analytical instruments and Michael D. Carducci for his help with the diffractometer. This study was supported by NSF ITR Grant PHY0219411, the Petroleum Research Fund and Coordenação de Aperfeiçoamento de Pessoal de Nível Superior (CAPES), Brazil.

\section{LITERATURE CITED}

BERNAL, J.D.; DASGUPTA, D.R. \& MACKAY, A.L. The oxides and hydroxides of iron and their structural interrelationships. Clay Miner. B., 4:15-30, 1959.

GÉHIN, A.; RUBY, C.; ABDELMOULA, M.; BENALI, O.; GHANBAJA, J.; REFAIT, P. \& GÉNIN, J.M.R. Synthesis of Fe(II-III) hydroxysulphate green rust by coprecipitation. Solid State Sci., 4:61-66, 2002.

GÉNIN, J.M.R. Fe(II-III) Hydroxysalt green rusts; from corrosion to mineralogy and abiotic to biotic reactions by Mössbauer spectroscopy. Hyperfine Interac., 156/ 157:471-485, 2004.

GÉNIN, J.M.R.; REFAIT, P.; BOURRIÉ, G.; ABDELMOULA, M. \& TROLARD, F. Structure and stability of the Fe(II)$\mathrm{Fe}(\mathrm{III})$ green rust "fougerite" mineral and its potential for reducing pollutants in soil solution. Appl. Geochem., 16:559-557, 2001.

GREAVES, C. \& THOMAS, M.A. Refinement of the structure of deuterated nickel hydroxide, $\mathrm{Ni}(\mathrm{OH})_{2}$, by powder neutron diffraction and evidence for structural disorder in samples with high surface area. Acta Crystallogr. B Struct. Sci., 42:51-55, 1986.

HANSEN, H.C.B.; GULDBERG, S.; ERBS, M. \& KOCH, C.B. Kinetics of nitrate reduction by green rusts - Effects of interlayer anion and Fe(II): Fe(III) ratio. Appl. Clay Sci., 18:81-91, 2001.

LIN, R.G.; SPICER, R.L.; TUNGATE, F.L. \& DAVIS, B.H. Study of the oxidation of ferrous hydroxide in slightly basic solution to produce gamma-FeOOH. Colloids Surfaces A-Physicochem. Eng. Aspects, 113:79-96, 1996.

LOYAUX-LAWNICZAK, S.; REFAIT, Ph.; EHRHARDT, J.J.; LECOMTE, P. \& GÉNIN, J.M.R. Trapping of $\mathrm{Cr}$ by formation of ferrihydrite during the reduction of chromate ions by $\mathrm{Fe}(\mathrm{II})-\mathrm{Fe}(\mathrm{III})$ hydroxysalt green rusts. Environ. Sci. Technol., 34:438-443, 2000.

O'LOUGHLIN, E.J.; KELLY, S.D.; COOK, R.E.; CSENCSITS, R. \& KEMNER, K.M. Reduction of uranium (VI) by mixed iron (II)/iron(III) hydroxide (green rust): Formation of $\mathrm{UO}_{2}$ nanoparticles. Environ. Sci. Technol., 37:721-725, 2003.

REFAIT, Ph. \& GÉNIN, J.M.R. Mechanisms of oxidation of $\mathrm{Ni}(\mathrm{II})-\mathrm{Fe}$ (II) hydroxides in chloride-containing aqueous media: Role of the pyroaurite-type Ni-Fe hydroxychlorides. Clay Miner., 32:597-613, 1997.

REFAIT, Ph.; ABDELMOULA, M.; SIMON, L. \& GÉNIN, J.M.R. Mechanisms of formation and transformation of $\mathrm{Ni}-\mathrm{Fe}$ layered double hydroxides in $\mathrm{SO}_{3}{ }^{2-}$ and $\mathrm{SO}_{4}{ }^{2-}$ containing aqueous solutions. J. Phys. Chem. Solids, 66:911-917, 2005.

REFAIT, Ph.; BAUER, Ph.; OLOWE, A.A. \& GÉNIN, J.M.R. The substitution of $\mathrm{Fe}^{2+}$ ions by $\mathrm{Ni}^{2+}$ ions in the green rust 2 compound studied by Mössbauer effect. Hyperfine Interact., 57:2061-2066, 1990.

REFAIT, Ph.; DRISSI, H.; MARIE, Y. \& GÉNIN, J.M.R. The substitution of $\mathrm{Fe}^{2+}$ ions by $\mathrm{Ni}^{2+}$ ions in green rust one compound. Hyperfine Interact., 90:389-394, 1994. 
REFAIT, Ph.; MEMET, J.B.; BON, C.; SABOT, R. \& GÉNIN, J.M.R. Formation of the $\mathrm{Fe}$ (II)-Fe(III) hydroxysulphate green rust during marine corrosion of steel. Corrosion Sci., 45:833-845, 2003.
STOOKEY, L.L. Ferrozine - A new spectrophotometric reagent for iron. Analytical Chem., 42:779-782, 1970. 